Article

\title{
Enhanced MODIS Atmospheric Total Water Vapour Content Trends in Response to Arctic Amplification
}

\author{
Dunya Alraddawi ${ }^{1}$, Philippe Keckhut ${ }^{1}$, Alain Sarkissian ${ }^{1, *}$ (D) , Olivier Bock ${ }^{2}$, \\ Abdanour Irbah ${ }^{1}$ (D), Slimane Bekki ${ }^{1}$, Chantal Claud ${ }^{3}$ and Mustapha Meftah ${ }^{1}$ \\ 1 Atmosphere, Environment and Spatial Observations Laboratory (LATMOS)/CNRS, 78280 Guyancourt, \\ France; dunia.alraddawi@latmos.ipsl.fr (D.A.); Philippe.Keckhut@latmos.ipsl.fr (P.K.); \\ Abdenour.Irbah@latmos.ipsl.fr (A.I.); Slimane.Bekki@latmos.ipsl.fr (S.B.); \\ Mustapha.Meftah@latmos.ipsl.fr (M.M.) \\ 2 IGN-LAREG, University Paris Diderot, 75013 Paris, France; Olivier.Bock@ign.fr \\ 3 LMD/IPSL, École Polytechnique, Université Paris Saclay, ENS, PSL Research University, \\ Sorbonne Universités, UPMC Univ Paris 06, CNRS, 91128 Palaiseau, France; chclaud@lmd.polytechnique.fr \\ * Correspondence: Alain.Sarkissian@latmos.ipsl.fr; Tel.: +33-(0)180-285-265
}

Received: 29 September 2017; Accepted: 28 November 2017; Published: 2 December 2017

\begin{abstract}
In order to assess the strength of the water vapour feedback within Arctic climate change, 15 years of the total column-integrated density of water vapour (TCWV) from the moderate resolution imaging spectrometer (MODIS) are analysed. Arctic TCWV distribution, trends, and anomalies for the 2001-2015 period, broken down into seasons and months, are analysed. Enhanced local spring TCWV trends above the terrestrial Arctic regions are discussed in relation to land snow cover and vegetation changes. Upward TCWV trends above the oceanic areas are discussed in lien with sea ice extent and sea surface temperature changes. Increased winter TCWV (up to $40 \%$ ) south of the Svalbard archipelago are observed; these trends are probably driven by a local warming and sea ice extent decline. Similarly, the Barents/Kara regions underwent wet trends (up to 40\%), also associated with winter/fall local sea ice loss. Positive late summer TCWV trends above the western Greenland and Beaufort seas (about 20\%) result from enhanced upper ocean warming and thereby a local coastal decline in ice extent. The Mackenzie and Siberia enhanced TCWV trends (about 25\%) during spring are found to be associated with coincident decreased snow cover and increased vegetation, as a result of the earlier melt onset. Results show drier summers in the Eurasia and western Alaska regions, thought to be affected by changes in albedo from changing vegetation. Other TCWV anomalies are also presented and discussed in relation to the dramatic decline in sea ice extent and the exceptional rise in sea surface temperature.
\end{abstract}

Keywords: water vapour; Arctic; trends

\section{Introduction}

Arctic amplification (AA) [1-6] is the phenomenon by which climate change is amplified in the Arctic with respect to global changes. It is partly related to the ice-albedo feedback mechanism. The Arctic region is experiencing a strong surface warming and a decrease in sea ice extent and thickness. This well-documented phenomenon [7] appears to be accelerating in the last decades. Several feedbacks are involved in the AA (e.g., [3,8-12]), notably those associated with the atmospheric hydrological cycle [13]. The warming of the lower part of the Arctic atmosphere [14] is found to be sensitive to the albedo changes due to increasing pollution agents (such as black carbon) on the Arctic sea ice/snow [15], loss of sea ice coverage, as well as the increase of the atmospheric northward transport of heat and moisture [16]. The spatiotemporal distribution of water vapour and the amplitude of its response to Arctic climate change are major sources of uncertainty in the understanding and 
prediction of the amplification mechanism [3]. Cloud and water vapour-related feedbacks to the AA are of enhanced interest [10,11].

This work assesses the long-term changes in atmospheric water vapour in response to the recent exceptional warming of the Arctic region within the period 2001-2015. We focus on the column-integrated water vapour amount, known as the total column of water vapour (TCWV), also called integrated water vapour. This amount is defined as the mass of water vapour in an atmospheric column over a unit area $\left(\mathrm{kg} \mathrm{m}^{-2}\right)$. It is sometimes referred to as precipitable water in satellite observations, which represents the height of liquid water (in $\mathrm{mm}$ ) that would result from the condensation of all the vertical column of water vapour over a unit area.

TCWV is characterized by a spatial and temporal variability, which is not yet completely understood over the Arctic. It affects the water cycle intensity and the atmospheric dynamics [17]. The global climate observing system (GCOS) considers the TCWV as an essential climate variable, with the priority of detecting both local and global TCWV trends using suitable data sets.

Ground-based and space-borne techniques can be used to study TCWV trends. Traditionally, radiosondes are the most favorable data, having the longest archives on a quasi-global scale. However, changes in the types of humidity sensors complicate the data analysis, especially from 1973 upwards [18] and mostly at the polar regions. References [19,20] analysed radiosondes data and reported a nearly global increase in surface-500-hPa precipitable water in a specific humidity for the 1973-1995 period. These upward trends are likely to be associated with the increasing global mean tropospheric temperature during this period, and hence the capacity of the atmosphere for holding water vapour. Satellites provide global coverage datasets, but they are still short compared to other techniques. Reference [21] used the special sensor microwave imager (SSM/I) global ocean data sets to assess the TCWV trends (in an extension of the study provided by [20]). Their results suggest positive trends from 1988 to 2003, connected with changes in sea surface temperatures (SST) for the North Atlantic area [22]. Merged with the scanning imaging absorption spectrometer for atmospheric chartography (SCIAMACHY) and the global ozone monitoring experiment (GOME) data set to analyze the global TCWV trends for the 1996-2002 period. They found positive trends over Greenland, East Europe, and Siberia. The Arctic-based TCWV trends studies are still limited. References [23,24] analyzed the atmospheric infrared system (AIRS) data for the 2003-2011 period and found regional positive TCWV trends over the Arctic Ocean. These trends were linked to coincident sea ice extent decline accompanied with enhanced regional evaporation rates. Using meteorological re-analyses, [25] examined changes in the Arctic TCWV for the 1979-2010 period. Similarly, positive Arctic TWCV trends are observed from 1979 to 2011, widespread over the Arctic during autumn and spring but centered over the Atlantic sector in winter [3]. These trends appear to be sensitive to downward long wave flux, which is in turn known to be sensitive to TCWV, and much more in winter than summer in the Arctic. Moreover, their simultaneous increase has a positive feedback to the AA [3]. The current publication follows these previous efforts and aims to study the interactions via the atmosphere-surface interface. The impact of 15 years of several interesting terrestrial Arctic changes on TCWV trends is studied via MODIS monthly dataset. This product, addressed for climatic purposes, has not been previously used (in limits of our knowledge) in similar TCWV studies in the Arctic region. The Arctic surface is defined here by land and ocean north of $60^{\circ} \mathrm{N}$.

Section 2 describes the used dataset. Section 3 presents the TCWV seasonal and monthly features. Section 4 examines the seasonal linear trends. Section 5 shows TCWV responses to certain amplification observations and discusses the results linked to snow cover, vegetation, SST, and sea ice area variability, while Section 6 concludes the paper.

\section{Data Set}

The passive-imaging spectro-radiometer with moderate resolution, MODIS, installed on the satellite TERRA (Earth Observation System EOS) since 1999, has now an important complete record from 2001 through 2016 and is still operating. On a polar orbit, MODIS/Terra passes over the equator 
at 10:30 a.m., and provides a global coverage within $1-2 \mathrm{~d}$, through a nadir-like geometry. The spatial resolution varies between $250 \mathrm{~m}$ and $1 \mathrm{~km}$ per pixel depending on the spectral band. MODIS observes the near-infrared solar radiation reflected by sufficiently bright surfaces and clouds. The 36 channels cover the spectral region $0.4-14.4 \mu \mathrm{m}$ and enable measurements of many trace gases in addition to cloud and aerosol properties.

Seasonal values used in this study are generated as the three-month average for that season [December-January-February (DJF), March-April-May (MAM), June-July-August (JJA), and September-October-November (SON)], with at least two available months for each seasonal value. Here we note that DJF (year) is considered as follows:

$$
\text { DJF (year) = average }(\text { December }(\text { year }-1) \text {, January (year), February (year)) }
$$

Monthly anomalies (used later in Section 5) are generated relative to the mean monthly values over the data period (2001-2015). Seasonal anomalies are calculated as the average of the three-monthly anomalies for that season. Correlations are considered for data time series after removing the trend's signal, as both compared time series have trends and these trends would give a false correlation if not removed; by removing trends, we could check for more realistic correlations. In this section, we present the various datasets used.

\subsection{MODIS TCWV}

Five Near-IR MODIS channels are useful for remote sensing of water vapour during the day [26]. These bands are $0.865,0.905,0.936,0.94,1.240 \mu \mathrm{m}$, in which all the surface types are sufficiently bright (albedo > 0.1). The external bands have no water vapour absorption features, but they are used to estimate the surface reflectance. The bands $0.905,0.936,0.94$ absorb water vapour with different sensitivity. $0.936 \mu \mathrm{m}$ has the strongest absorption sensitivity; it is used mostly for drier condition measurements, while the weak absorption channel at $0.905 \mu \mathrm{m}$ is useful for measurements at low solar elevation. TCWV can be derived from absorbed and non-absorbed nearby channels. Its accuracy is claimed to be $5-10 \%$ [26]. Errors would result from observations during atmospheric hazy scenes, or over dark surfaces.

This study uses the 15-year (2001-2015) TCWV from MODIS, namely the product MOD08_M3, clear column, level 3 , monthly global $1^{\circ} \times 1^{\circ}$ gridded data set, from the Terra platform. This data is freely available at ftp:/ /ladsweb.nascom.nasa.gov/allData/6/MOD08_M3. More information about this data set can found at https:/ / modis.gsfc.nasa.gov/data/dataprod/pdf/MOD_08.pdf. The MODIS TCWV used refers to water vapour near infrared clear column over bright surfaces and over the ocean by sun glint only. This monthly product has been calculated as the mean of Level 3 weighted daily means. The metadata includes many details on the content and pixel nomination method.

However, we would like to highlight the uncertainty of MODIS TCWV data set which was found to be more sensitive to clouds presence during summer, this problem is cited by the authors of this paper in a previous validation effort of the same used dataset over the polar regions during all the studied period (all seasons) [27].

\subsection{MODIS Snow Cover}

Section 5 discussed the TCWV trends over land with response to the snow cover variability; the discussion is carried out using MODIS snow/ice cover monthly product (MOD10CM) from version 6, freely available at https:/ /n5eil01u.ecs.nsidc.org/MOST/MOD10CM.006.

The monthly average snow cover data set is reported in 0.05 degree (approx. $5 \mathrm{~km}$ ) resolution climate modelling grid (CMG) cells, while the monthly averages are computed from daily snow cover observations in the MODIS/Terra Level 3 global product named (MOD10C1) data set. Throughout our study, the $0.05^{\circ}$ monthly values are screened to be coherent with the used TCWV data $\left(1^{\circ}\right)$. 
The MODIS snow cover products provide fractional snow cover; data are ranged from $0(0 \%$ of the area is covered with snow in this pixel) to $1(100 \%$ of the pixel area is fully snow covered). The overall absolute accuracy of MODIS snow cover daily products is about $\sim 93 \%$, varying by land cover, topography, and season [28]. The largest factor affecting the accuracy of the MODIS snow products is snow cloud confusion. However, The MODIS cloud mask [29] problem concerns mainly Antarctica [28].

\subsection{MODIS Vegetation Index}

The TCWV response to the Arctic terrestrial vegetation changes is also investigated by means of the normalized difference vegetation index (NDVI) from MODIS [30]; this index is widely used over the Arctic [31]. The monthly MODIS/Terra vegetation index used (MOD13C2) is also from version 6, publicly available on ftp://ladsweb.nascom.nasa.gov/allData/6/MOD13C2; more details on this product can be found at https://lpdaac.usgs.gov/dataset_discovery/modis/modis_products_table/ mod13c2_v006.

The normalized difference vegetation index (NDVI) is defined based on the different reflectivity of green plants with different wavelengths. More clearly, the contrast between red and near-infrared responses is a sensitive measure of vegetation amount, with maximum (red, NIR) differences occurring over a full canopy and minimal contrast over targets with little or no vegetation [30]. NDVI is calculated by rationing the difference between the NIR and red band reflectance by their sum as the following:

$$
\text { NDVI }=(\text { NIR }- \text { RED }) /(\text { NIR }+ \text { RED })
$$

where NIR is surface reflectance in the near infrared $(0.725-1.1 \mathrm{~mm})$ and RED is the reflectance in the visible radiation $(0.55-0.70 \mathrm{~mm})$. The gridded NDVI maps used here are produced from MODIS surface reflectance corrected for molecular scattering, ozone absorption, and aerosols, as input to the algorithm equations. They have a spatial resolution of $0.05^{\circ} \times 0.05^{\circ}$, so they are screened in a similar way to snow cover data set to finally have the same $1^{\circ} \times 1^{\circ}$ resolution as that of TCWV data set. The NDVI data set has the valid range from -0.2 to 1 , where negative data refers to ice, water, or snow covered regions, while data near 0 is coincident to bare soil.

\subsection{MODIS Sea Surface Temperature}

The sea surface temperature is defined as the temperature $\left({ }^{\circ} \mathrm{C}\right)$ of the nearest sea (ocean) layer to the atmosphere. We use the MODIS Terra global Level 3 mapped SST products derived from the $11 \mathrm{um}$ thermal infrared (IR) band (channel 31), which belongs to the latest MODIS SST reprocessing (R.2014.0)—ftp:/ / podaac-ftp.jpl.nasa.gov/allData/modis/L3/docs/ UserGuideMODISL3v2014.0.pdf-as daytime mid-IR SST products are known to suffer from reflected sunlight contamination.

The monthly MODIS SST product was chosen with spatial resolution of $9.26 \mathrm{~km}$ for daytime passes. The SST data global uncertainty is about \pm 0.1 degrees Celsius. This data set is freely available and detailed at ftp://podaac-ftp.jpl.nasa.gov/allData/modis/L3/terra/11um/v2014.0/ $9 \mathrm{~km} /$ monthly, ftp:/ / podaac-ftp.jpl.nasa.gov/allData/modis/L3/docs/MODIS_SST_Guide_Doc.pdf. The $0.083^{\circ} \times 0.083^{\circ}$ MODIS thermal SST data set is screened to $1^{\circ} \times 1^{\circ}$ to match the TCWV data set, and thereby to be coherently used in the discussion carried out in Section 5 .

\subsection{NSIDC Sea Ice Extent}

In order to assess the TCWV response to the extent of sea ice changes through the 2001-2015 periods, we use sea ice extent (concentration, area) data from the National Snow and Ice Data Centre (NSIDC) version 2, identified as G02135 [32], available at ftp:/ / sidads.colorado.edu/DATASETS / NOAA/G02135/north/monthly. 
This data set is generated from brightness temperature data and is designed to provide a consistent time series of sea ice concentrations spanning the coverage of several passive microwave instruments, the scanning multichannel microwave radiometer (SMMR), the special sensor microwave imager (SSM/I), and special sensor microwave imager sounder (SSMIS), on board of the defence meteorological satellite program (DMSP, DMSP 5D-3/F17, DMSP 5D-3/F18, Nimbus-7) from the National Oceanic and Atmospheric Administration (NOAA). The data are provided in the polar stereographic NSIDC projection at a grid cell size of $25 \times 25 \mathrm{~km}$. They are screened to $1^{\circ} \times 1^{\circ}$ to enable the comparison with TCWV.

\section{TCWV Features}

Spatial TCWV variability generally depends on latitude, orography, continental underlying surface type, and atmospheric condition, among other conditions. The temporal variability is found to be mainly linked to air temperature changes (IPCC 4 th report), with maximum sensitivity during the colder seasons over the Arctic. Figure 1 shows the averaged Arctic TCWV distribution in the 12 months from 2001 to 2015, while the four seasons mean TCWV are presented in Figure 2.
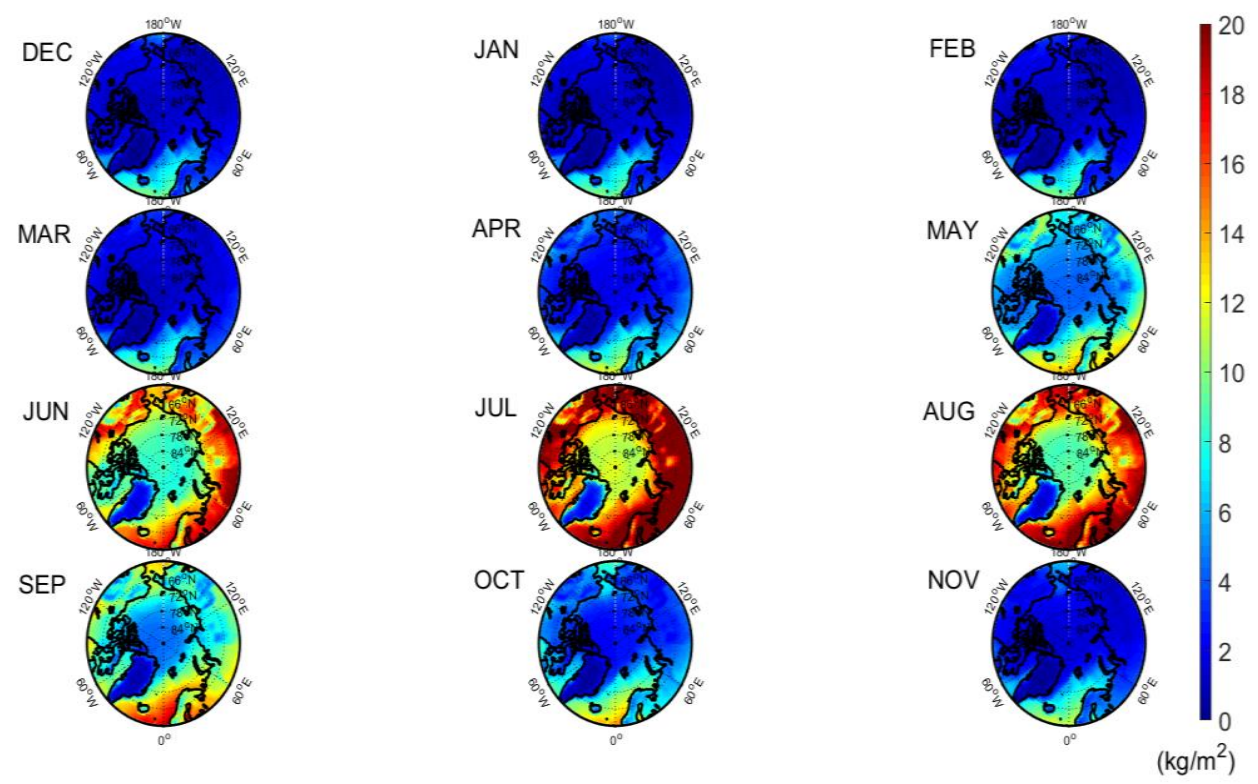

Figure 1. Monthly distribution of 2001-2015 total column-integrated density of water vapour (TCWV) mean in $\mathrm{kg} \mathrm{m}^{-2}$.

Consequently, Arctic TCWV decreases towards the pole. Snow season normally starts in October, and this season is characterized by glacial surfaces on land (permafrost, snow, etc.) and on oceans (sea ice, snow, etc.). It also witnesses the lowest temperatures, and thereby a lower TCWV (Clausius-Clapeyron relationship). For 6 months of the year, almost no solar radiation reaches the North Pole. Driest conditions (DJF TVWV below $5 \mathrm{~kg} \mathrm{~m}^{-2}$ ) dominate over Greenland, East Siberia, North Canada, the Arctic Ocean and its surrounded ice-covered seas. The Atlantic sector has more ice-free zones and thereby has wetter relative conditions (TCWV up to $8 \mathrm{~kg} / \mathrm{m}^{2}$ ); these conditions are modified by the North Atlantic circulations coming from lower latitudes in winter.

The rising temperatures help to start the snowmelt in April (or later, depending on local, regional, and inter-annual variability $[6,33])$. Within the watershed permafrost degradation period, river flows resume their movements towards the Laptev and East Siberian Seas [34], and the spring re-vegetation favours wetter conditions in May (about $10 \mathrm{~kg} / \mathrm{m}^{2}$ ) by evapotranspiration [35] at the Siberian/Mackenzie watersheds (Figure 1). However, the Atlantic sector is still the most humid region, with TCWV values reaching $14 \mathrm{~kg} / \mathrm{m}^{2}$ in spring. 
Summer months witness a nearly-complete presence of sunlight, and more open waters, in addition to the majority of liquid precipitation, especially above the vegetated European Arctic, Siberia, and north Canada [35]; all the previous conditions favour more humid atmospheric columns. The most humid TCWV is observed in July, with an average TCWV exceeding $25 \mathrm{~kg} / \mathrm{m}^{2}$ for most regions, but lower TCWV values are observed at the higher altitudes (including the Norwegian and Ural Mountains, the Central Siberian uplands, the Chukchi and Verkoyansk ridges, and the Rocky Mountains). The central Arctic Ocean has an even drier TCWV, with averaged JJA around $14 \mathrm{~kg} \mathrm{~m}^{-2}$; the driest conditions are reported at the Greenland ice sheet with a TCWV less than $5 \mathrm{~kg} / \mathrm{m}^{2}$ in interior Greenland.
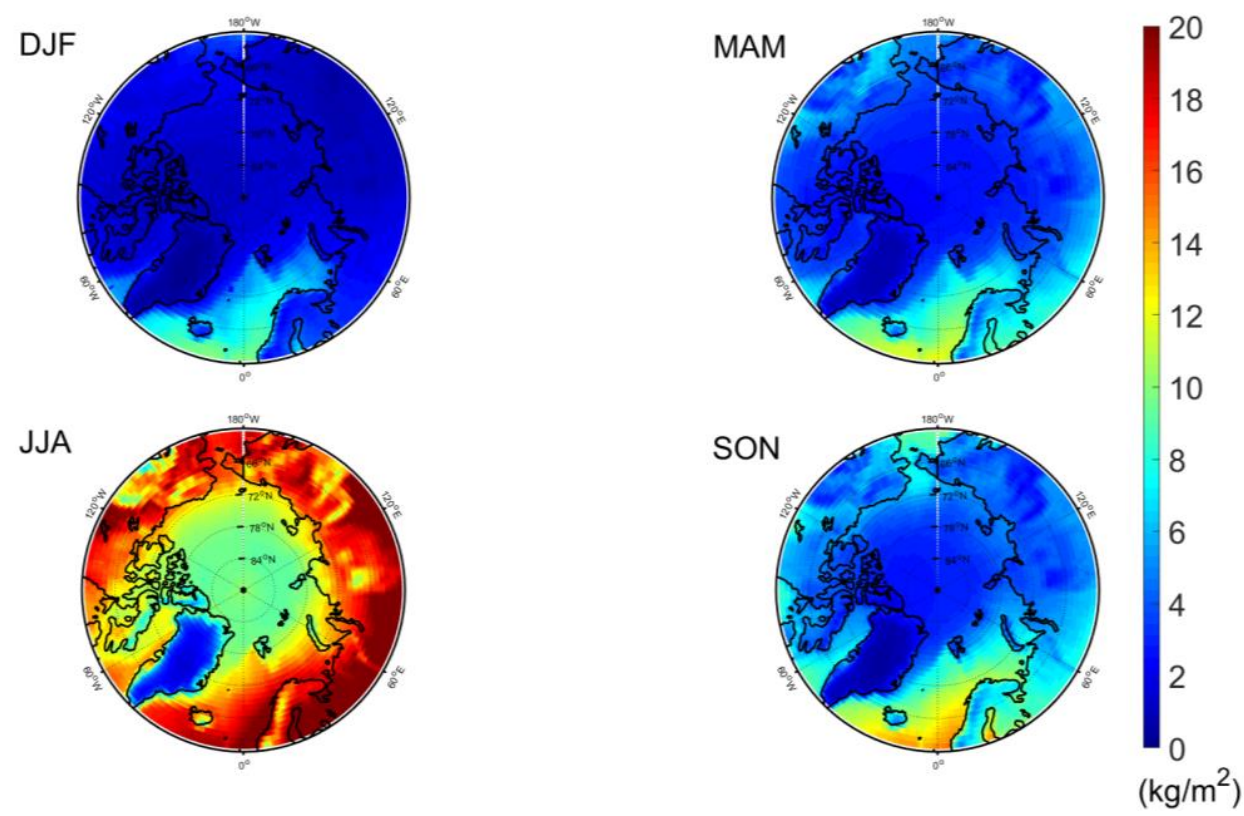

Figure 2. Seasonal distribution of 2001-2015 TCWV mean in $\mathrm{kg} \mathrm{m}^{-2}$. Note that winter TCWV mean is carried out for 2002-2015 (December-January-February, DJF).

\section{TCWV Linear Trends and Discussion}

Water vapour is a good indicator of the climate system responses to global and therefore Arctic warming $[3,36]$. We now investigate the linear trends over all seasons. TCWV data are filtered and pixels with one or more missing months are omitted (marked in white in Figure 3); then, trends were calculated from a least-square fit for the remaining pixels. Figure 3 presents the significant absolute TCWV linear trends at the $95 \%$ confidence level. Trends are considered with respect to the first year of the record (2001) for a given month (or season), at each pixel separately. Mean relative trend formal errors are $15 \%, 12 \%, 10 \%$ and $12 \%$ in DJF, MAM, JJA, and SON respectively.

Increased TCWV winter/fall trends are observed at the Svalbard region with up to $2 \mathrm{~kg} / \mathrm{m}^{2}$, and slightly decreased trends are observed south of Iceland and in south-western Greenland seas.

Upward TCWV trends (up to $2 \mathrm{~kg} \mathrm{~m}^{-2}$ ) are observed over the Barents, Kara, and Laptev seas in the transition seasons, reaching its maximum over some parts of the Barents sea in spring, and over most of the three seas in fall. These trends are already noticed in winter time in the Barents Sea area (south of Svalbard) with more than $2 \mathrm{~kg} \mathrm{~m}^{-2}$.

Enhanced spring TCWV trends are observed over the Siberian tundra and the Mackenzie watershed and the neighbouring coasts with up to $1 \mathrm{~kg} \mathrm{~m}^{-2}$.

Summer enhanced trends of up to $3 \mathrm{~kg} \mathrm{~m}^{-2}$ are observed in the Beaufort Sea, and of about $1 \mathrm{~kg} / \mathrm{m}^{2}$ in the western Greenland summer open water region. Generally, MODIS data does not show important TCWV trends at the terrestrial Greenland regardless of the season. 
Downward trends are mostly pronounced at the terrestrial Arctic in summer with TCWV up to $3 \mathrm{~kg} / \mathrm{m}^{2}$; this is also the case in the fall, but with a weaker magnitude (less than $1 \mathrm{~kg} / \mathrm{m}^{2}$ ).

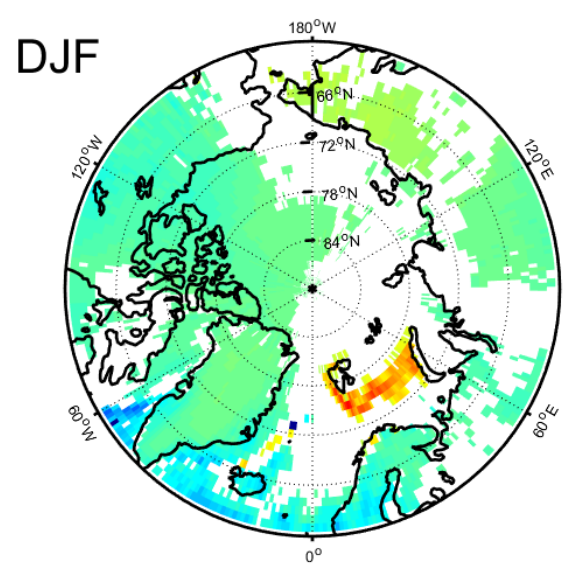

JJA

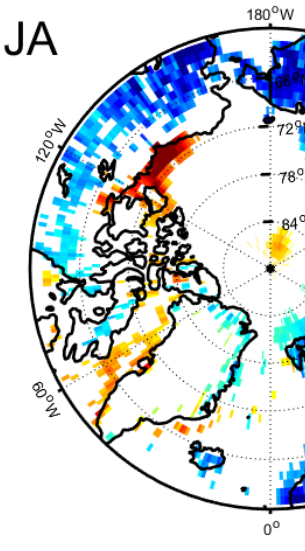

$0^{\circ} \mathrm{W}$
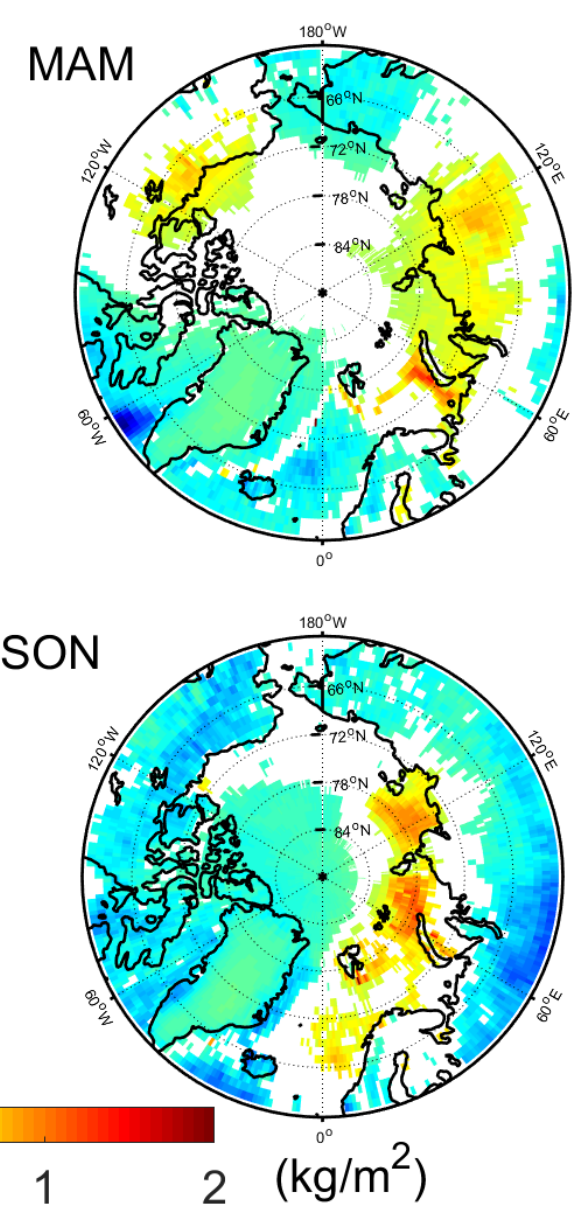

Figure 3. Seasonal TCWV linear trends in $\mathrm{kg} \cdot \mathrm{m}^{-2} /$ decade of 2001-2015. DJF trends were calculated for 2002-2015, while March-April-May (MAM), June-July-August (JJA), and September-October-November (SON) were calculated for 2001-2015. Statistically significant trends at the $95 \%$ confidence level based on a Student's t test are shown in color. Pixels with missing data or not-significant trends at the $95 \%$ confidence level are in white.

\section{General Discussions}

Increasing winter and fall air temperature and precipitation have already affected Svalbard [37]. Additionally, reference [38] has stated a loss in the winter ice extent and concentration north of Svalbard, which could have an extra positive feedback on TCWV trends.

Earlier melt onset in the Barents, Kara, Laptev, and Beaufort seas [39] could contribute to wetter-than-averaged spring TCWV amounts, and thereby a MAM TCWV positive trend in addition to the reported increased freshwater discharge of the Mackenzie River into the Beaufort Sea by about $25 \%$ since 2003 [40].

Arctic fall sea ice extent at the eastern part of the Arctic ocean (against the Siberian west and middle coasts) has a downward trend. This local sea ice cover reduction has increased the vertical heat flux in autumn and early winter [7], and has locally increased the air temperature [3]. All these mechanisms could explain the wet local TCWV SON trend.

The Beaufort Sea has experienced a summer sea ice extent/area decline in 2007 and 2012, with a deformation towards thinner ice, earlier melt onset, later freeze-up, and thereby longer periods of open water [41,42]. This region is exposed to heat flux fed by the Pacific circulations across the Bering 
Strait [43] coincident with clearest skies and thereby enhanced down welling radiation. Within the clearest conditions, MODIS measurements are more reliable, and an increasing summer trend (around $2 \mathrm{~kg} / \mathrm{m}^{2}$ ) is observed. Similar increasing trends are observed also in MAM (Figure 3) but with weaker magnitude. Both trends are consistent with local increased evaporation rates seen by other instruments [23].

A record observed Greenland ice-sheet melt during summer 2012 (July), is thought to be forced by a warmer atmosphere (with record air temperature anomalies at the 600-700 hPa), which induces more frequent southerly warm air advection along the western Greenland coast and over the neighboring Canadian Arctic archipelago [44] and low liquid clouds [45] associated with new near-surface air temperature records, during the whole summer months of 2012 [46]. A loss in sea ice coverage in these regions could have helped to cause increases in TCWV.

The current study discusses upward TCWV trends with respect to certain Arctic changes (Section 5); the negative TCWV trends are not discussed in this paper, as they need further investigation.

\section{TCWV Responses to Arctic Amplification}

In general, Arctic amplification is characterized by spatial and temporal variability, affected by atmospheric circulation patterns [47,48], sea ice conditions [49], and ocean surface temperature [50].

The Arctic climate undergoes many changes, with seasonal and regional features [51]. According to the IPCC report of 2014, widespread expansion of shrubs and other vegetation is taking place around the tundra biome, known as the greening of the Arctic. Some recent studies assert that, during non-summer seasons, some Arctic regions are generally becoming a source of carbon rather than a sink [52], forced by changes in albedo, and enhanced by permafrost increased temperature $[53,54]$ and therefore thawing.

Since 2000, many observations have stated this change, including an Arctic persistence winter warmed phase [55], unprecedented September sea ice declines (according to the NSIDC, [32]) and regional summer upward trends of sea surface temperature [56].

Our current study tracks the TCWV change during exceptional events at the Arctic. Many MODIS data sets are used, including the sea surface temperature (SST) $\left({ }^{\circ} \mathrm{C}\right)$, snow cover product (fraction), and normalized differential vegetation index (NDVI) (fraction), in addition to the NSIDC sea ice extent data set, all of which were detailed previously in Section 2.

\subsection{Spring and Summer TCWV Trends in Response to NDVI and Snow Cover Changes}

The initial modification of the Arctic vegetation (as one of the impacts of the recent climate changes) takes place at the vegetation boundaries of the Arctic tundra. Increases in vegetation productivity have been observed across the Arctic (e.g., [57]), and recent analyses suggest that the general increases in productivity concern all vegetation types [58]. We try to trace these changes and show when and where the TCWV has its most notable response to them. Additionally, we inspect how the snow cover trends evolve for the same studied period of spring 2001-2015. Figure 4 shows the TCWV, NDVI, and snow cover linear trends at the 95\% significant level in spring (2001-2015), as well as the correlations between the TCWV and each of NDVI and snow cover. The enhanced TCWV trend over the Siberian and Mackenzie lands is found to be coincident with enhanced NDVI trends and decreased snow cover, which refers to the earlier snowmelt onset cited previously for both regions (Section 4). Additionally, the inter-annual variability of TCWV in spring shows a significant positive correlation with NDVI, while an opposite correlation with the snow cover fraction appears (Figure 4).

The above-mentioned regions also underwent a maintaining decreased snow cover surfaces, and the later snow seems to be replaced by green areas. These green areas transfer extra water vapour to the atmosphere by evapotranspiration. 

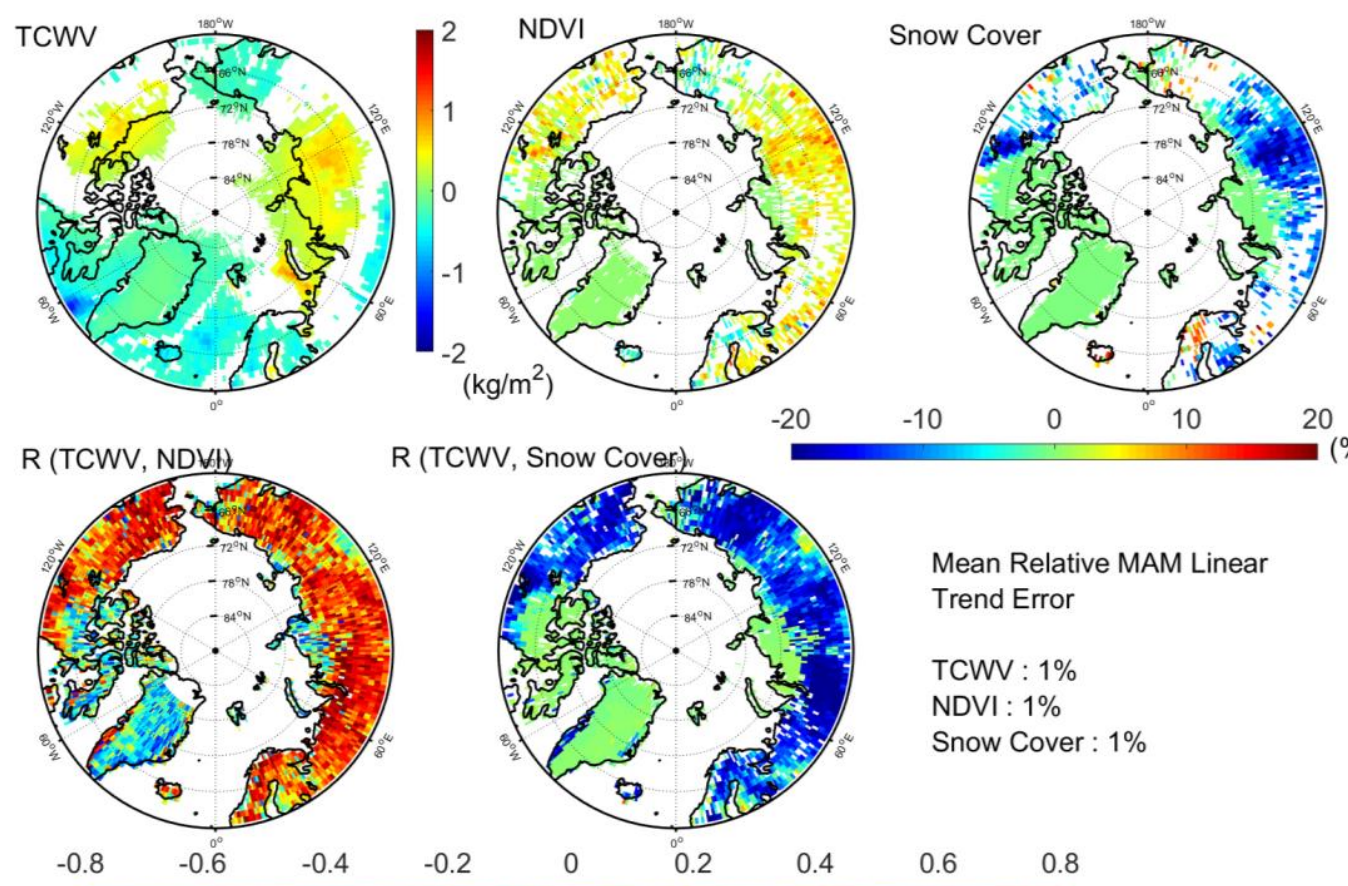

Mean Relative MAM Linear Trend Error

TCWV : $1 \%$

NDVI : $1 \%$

Snow Cover : $1 \%$

Figure 4. (Upper plots) Absolute trends in MAM of TCWV, normalized differential vegetation index (NDVI), and snow cover from left to right, respectively. Lower plots: Correlation coefficients in MAM of (left) TCWV with NDVI and (right) TCWV with snow cover for the whole 15 years of data. Note that TCWV trends are in $\mathrm{kg} / \mathrm{m}^{2} /$ decade, and NDVI and snow cover use the same colour bar (bottom); their trends are in \%/decade. Both correlation maps use the colour bar at the bottom. Only statistically significant trends at the $95 \%$ confidence level based on a Student's $t$ test are shown. Pixels with missing data or not significant trends at the $95 \%$ confidence level are in white.

Increased NDVI trends have been previously observed in the Beaufort region coasts and inlands [59], driving the evapotranspiration rates and thereby contributing to the local wet TCWV trends observed in MAM and JJA (Figures 4 and 5).

In summer (Figure 5), nearly all the Siberian lands show slightly enhanced vegetation areas, but with no significant magnitude of snow cover trends. MODIS TCWV trends above the eastern terrestrial arctic and western Alaska show a negative trend, and the correlated patterns of summer TCWV and each of NDVI and snow cover are scattered and do not show a spatially consistent feature. The decreased summer TCWV trends in the Siberian and Canadian regions are observed as coincident with slightly increased vegetation.

In response to higher summer temperatures, increased vegetation productivity and shrub expansion are observed in many sites of Alaska and Siberia [60,61]. Increased shrub cover in the Arctic is expected to have major implications for the energy exchange between the land surface and atmosphere [62]. Experimental studies reveal that deciduous shrub expansion, within the early spring onset melt and thereby the longer shrub growing season, may reduce the summer permafrost thaw and the surface albedo [63-65]. Additionally, soil temperature (under shrubs) is found to be reduced in summer (e.g., [66]). Moreover, the boreal Eurasia undergoes warmer summers without increased precipitations; they are vulnerable to drought stress and fire regime shifts $[67,68]$. All previous studies show signs of drier summers over some Siberian and Alaskan regions. However, we do believe that further investigations (not provided by this study) are still needed to better discuss and explain these trends.

The MODIS TCWV data set seems to be able to detect the enhanced TCWV trends in summer at the western Greenland and Beaufort seas (Figure 5). This ability is thought to be due to clearer 
summer conditions over both regions [69], and thereby more realistic MODIS TCWV local summer measurements [27]. TCWV summer trends at the oceanic part are to be discussed again later with respect to sea surface temperature trends.
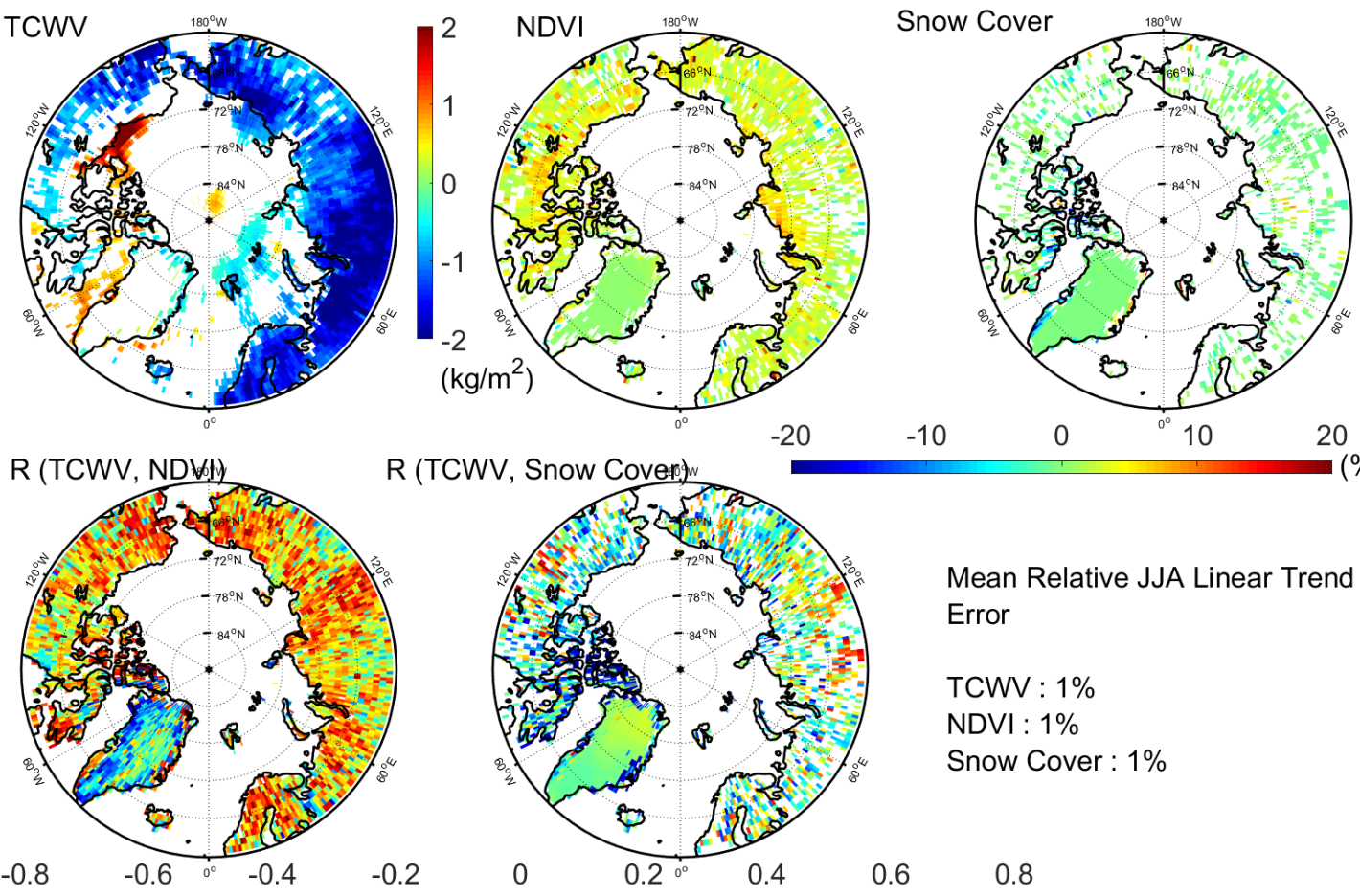

$-20$

$-10$

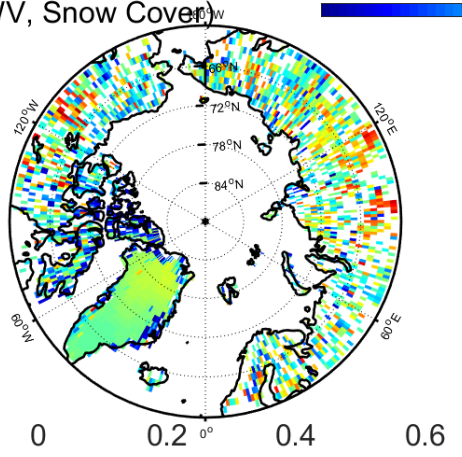

Mean Relative JJA Linear Trend Error

TCWV : $1 \%$

NDVI : $1 \%$

Snow Cover : $1 \%$

Figure 5. Upper plots: Absolute trends in JJA of TCWV, NDVI, and snow cover from left to right, respectively. Lower plots: Correlation coefficients in JJA of (left) TCWV with NDVI and (right) TCWV with snow cover for the whole 15 years of data. Note that TCWV trends are in $\mathrm{kg} / \mathrm{m}^{2} /$ decade, and NDVI and snow cover use the same colour bar (bottom); their trends are in \%/decade. Both correlation maps use the colour bar at the bottom. Only statistically significant trends at the $95 \%$ confidence level based on a Student's $t$ test are shown. Pixels with missing data or not significant trends at the $95 \%$ confidence level are in white.

\subsection{TCWV Response to Regional Upper Ocean Warming (TCWV Trends in Response to SST Trends)}

Enhanced solar heating of the upper ocean has been observed over the Beaufort [56] and the western Greenland seas [70] in July and August. This results in positive local SST trends over both regions. However, the MODIS TCWV data response to these trends is not the same. More clearly, the Beaufort Sea region shows enhanced TCWV trends in both July and August (Figure 6) coincident with enhanced SST trends. Nevertheless, the enhanced TCWV trends over the west Greenland seas are observed only in July, but no longer in August (Figure 6). Please also note the TCWV response to the increased SST in the Barents Sea region in June. The previously-mentioned zones of wet TCWV trends are affected by the principal paths of the meridional humid flux [71] into the Arctic in summer [35].

One case study could be the exceptional Augusts of 2007 and 2012 (Figure 7). In 2007, the SST showed an enhancing anomaly of more than $50 \%$ in the Laptev, the eastern Siberian, and the Baffin Bay, but not as obviously in the Chukchi Sea. These anomalies were coincident to wet TCWV anomalies that extended to the whole northern and eastern Canadian archipelago and more strongly towards the Arctic Ocean from most sides. 


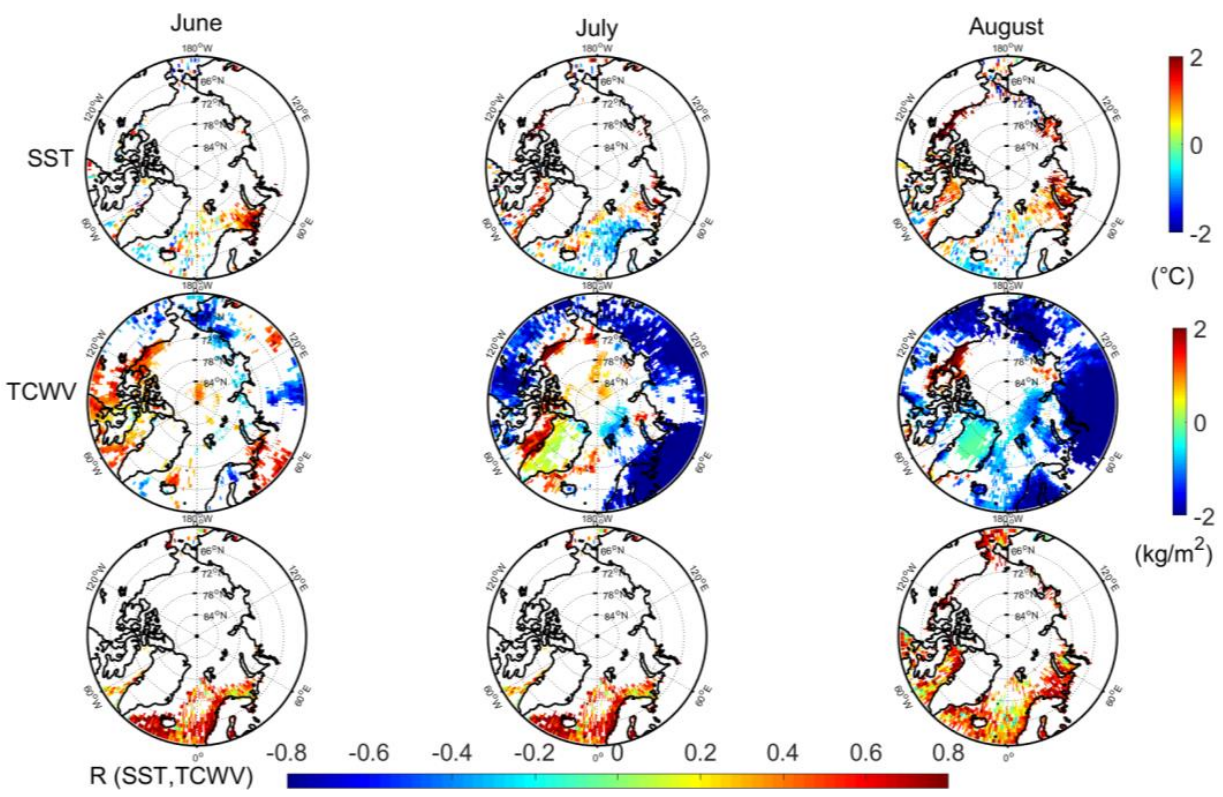

Figure 6. Upper plots: Absolute trends of SST in June, July, and August from left to right, respectively, by ${ }^{\circ} \mathrm{C} /$ decade of (2001-2015). Middle plots: Absolute trends of TCWV in June, July, and August from left to right, respectively, by $\mathrm{kg} / \mathrm{m}^{2} /$ decade of (2001-2015). Lower plots: Correlation coefficients of TCWV with SST in June (left), July (middle), and August (right) for the whole 15 years of data. Trend colour bars are on the right. Correlation maps use the colour bar on the bottom. Only statistically significant trends at the $95 \%$ confidence level based on a Student's t test are shown. Pixels with missing data or not significant trends at the $95 \%$ confidence level are in white

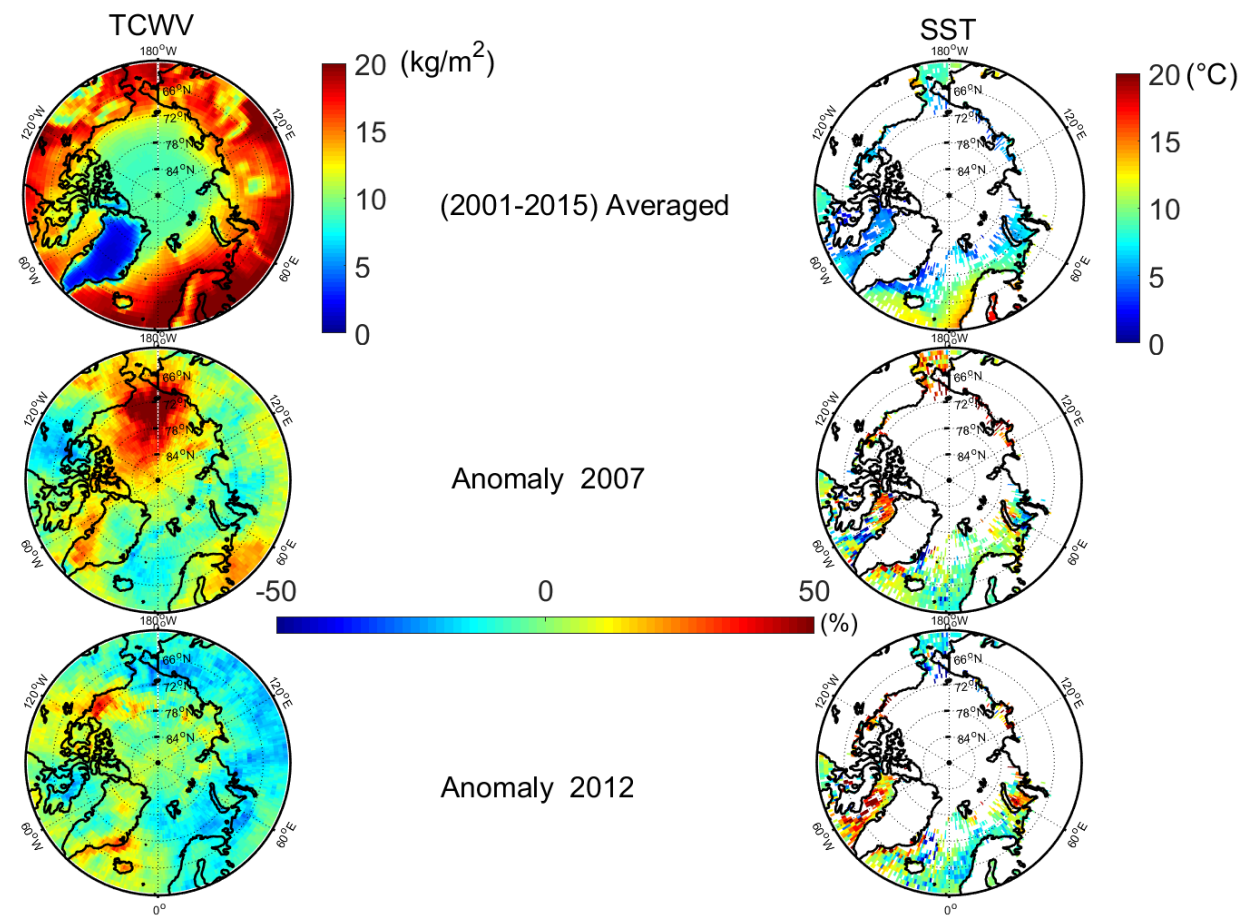

Figure 7. TCWV anomaly during the exceptional August of 2007 and 2012 with respect to (2001-2015) mean. Upper plots: Averaged August TCWV, SST for 2001-2015 by kg/m ${ }^{2},{ }^{\circ} \mathrm{C}$ from left to right, respectively. Middle plots: 2007 August anomaly of TCWV, SST (\%), respectively; and lower plots show the same as the second but for 2012 . 
Again in 2012, and out of the Chukchi Sea, the upper ocean warming was more distinguished in the Denmark Strait, Baffin Bay, and Davis straits, and the southeastern Greenland Sea as well as at the Beaufort open water. Consequently, these warm spots drove a wetter than usual coincident anomaly of TCWV (weaker at the Davis Strait, while no wet trends are observed at the Kara Sea).

Overall, we do believe that the wet TCWV trends are driven by the local dramatic observed sea ice decline in 2007 and 2012 (stated previously in Section 4) more than the locally enhanced SST trends. Logically, both unusual late summers have resulted in dramatic September sea ice extent decline in 2007 and 2012, which will be discussed below.

\subsection{TCWV Response to Sea Ice Extent Retreat}

Many studies state that the Arctic sea ice has experienced a shift from abundant perennial ice to predominantly seasonal ice [72,73]. Sea ice extent is considered for areas having more than $15 \%$ ice concentration. The seasonal cycle of the Arctic sea ice extent is characterized by a minimum in September and a maximum in March.

The accelerated sea ice melting would increase the open water areas after the summer warming. Most of these regions are on the northern North Atlantic and the Barents-Kara in winter, and above the Beaufort Sea in summer, while above the Chukchi sea and the Bering Strait in early fall.

\subsubsection{September Sea Ice Extent Decline in 2007 and 2012}

Sea ice extent negative anomaly phase has been clearly observed since 2001 according to NSIDC analysis (Figure 8), with the most dramatic declines in September 2007 and September 2012 [74-76]. Moreover, most coasts above $70^{\circ} \mathrm{N}$ experience longer ice-free periods as a result of earlier melt onset and later freeze-up [41]. September TCWV linear trends are thought to be sensitive to the sea ice extent changes per decade of the study period of 2001-2015.

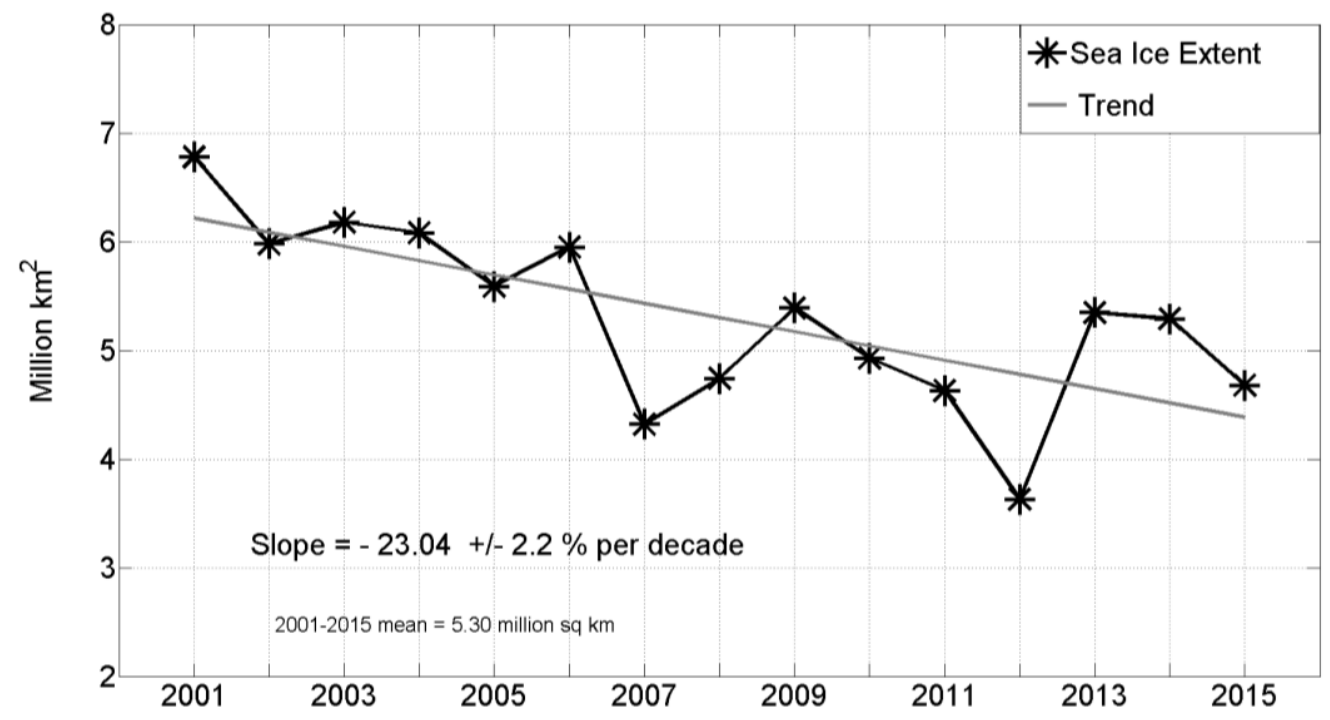

Figure 8. September Sea ice extent linear trend over $60^{\circ} \mathrm{N}-90^{\circ} \mathrm{N}$ with respect to 2001-2015 mean. The shown trends are statistically significant at the $95 \%$ confidence level based on a Student's $t$ test. Data are from the National Snow and Ice Data Centre (NSIDC).

Within the study of [77], the Chukchi and Beaufort sea ices showed a strong and pronounced variability with a large decrease from $90 \%$ in April to about $10 \%$ in September, unlike the Greenland Sea ice variability, which is rather small. However, for both zones, the sea ice concentration is shown to be inversely correlated with specific humidity and temperature. Here, we present only the TCWV anomalies for September to show the regional response to the decline of sea ice extent. Figure 9 
shows the most dramatic September sea ice declines, and the local and greater coincident TCWV positive anomaly.
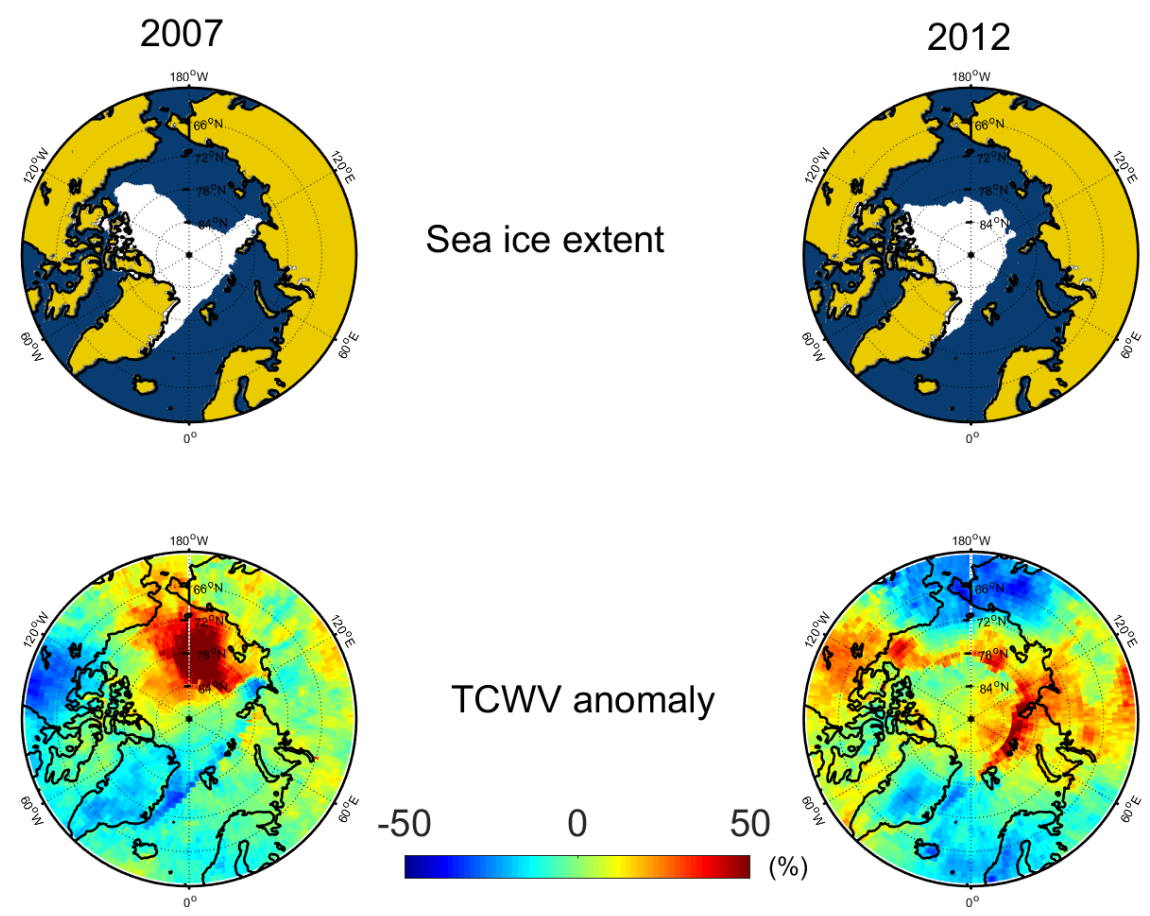

Figure 9. September sea ice extent (white areas of the upper plots) and TCWV anomaly (\%, lower plots) for 2007, and 2012. Anomaly is calculated with respect to (2001-2015) mean.

\subsubsection{Barents and Kara Amplification}

Enhanced Atlantic downward infrared radiation has contributed to local winter sea ice decline, particularly in the Barents-Kara seas and Baffin Bay $[47,78]$.

The net radiation budget has a clear enhanced trend since 2001 over Svalbard, with enhanced downward long wave radiation in winter [79].

TCWV winter trends show a positive response to the mentioned local winter sea ice decline (Figure 3). Here we select two domains of $5^{\circ}$ by $5^{\circ}$ located over the Barents Sea and over the Kara Sea (Table 1), to show the winter and fall TCWV in both regions respectively. The selected squares belong to the region that shows an enhanced TCWV trends (Figure 3).

Table 1. Localisation of both examined TCWV regions of the Barents and Kara Seas.

\begin{tabular}{ccc}
\hline Region & Latitude Range & Longitude Range \\
\hline Barents & $75^{\circ} \mathrm{N}-79^{\circ} \mathrm{N}$ & $30^{\circ} \mathrm{E}-34^{\circ} \mathrm{E}$ \\
Kara & $76^{\circ} \mathrm{N}-80^{\circ} \mathrm{N}$ & $85^{\circ} \mathrm{E}-89^{\circ} \mathrm{E}$ \\
\hline
\end{tabular}

Regionally averaged winter (fall) time series of both TCWV (squares) and sea ice area (all area) for the Barents (Kara) regions are presented (Figure 10). Note that winter sea ice area time series represent the regional averaged winter NSIDC data set (for the whole Barents/Kara Sea) calculated for the same period 2002-2015, while the TCWV regional average is the average of the selected square (Table 1). Figure 10 highlights clearly the significant inversed correlations between TCWV and sea ice area time series for the studied period, with negative correlations coefficients of about $-68 \%,-58 \%$ for Barents in DJF and Kara in SON respectively, agreeing with [77]. This confirms that the observed SON and DJF local enhanced TCWV trends are temporally sensitive to the local sea ice decline over the studied seas. 


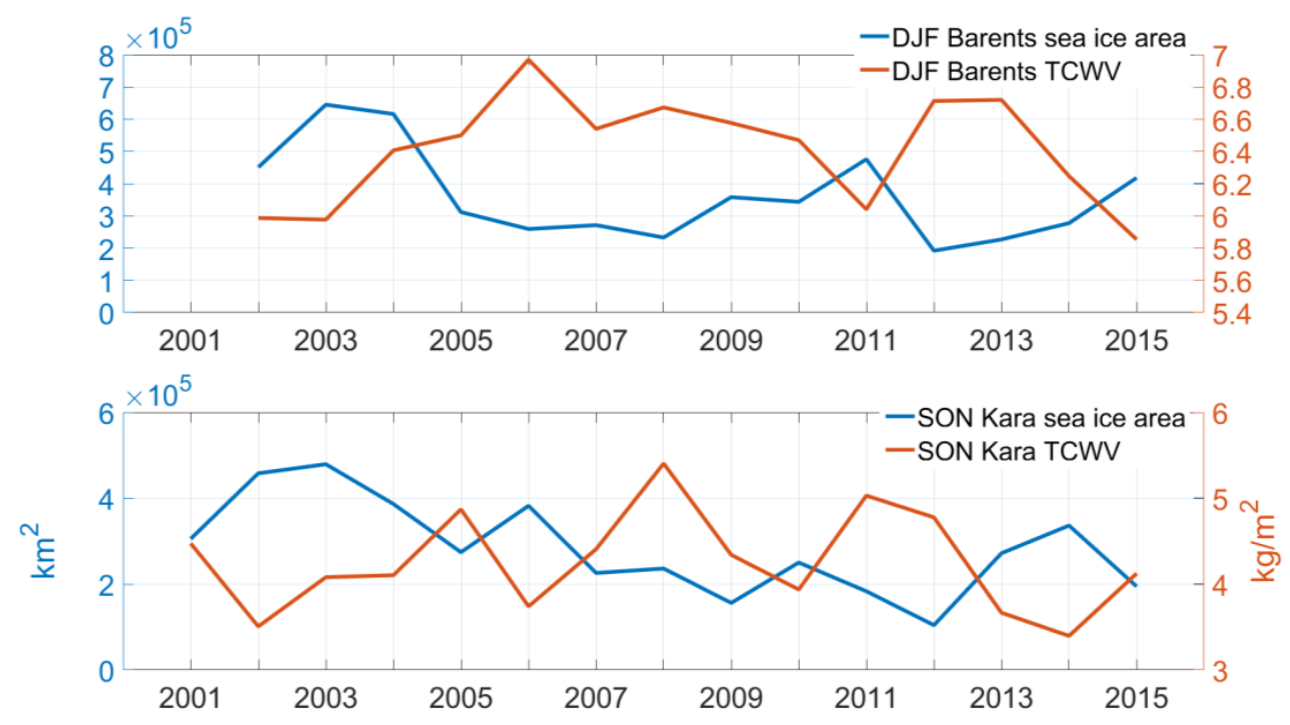

Figure 10. Regionally averaged time series of sea ice area $\left(\mathrm{km}^{2}\right)$ and TCWV $\left(\mathrm{kg} / \mathrm{m}^{2}\right)$ from 2001 to 2015 in winter (DJF) for the Barents Sea and in fall (SON) for the Kara Sea. Note that TCWV studied regions are defined in Table 1.

\section{Conclusions}

TCWV trends are assessed for 15 years of the recent Arctic amplification phases using the MODIS monthly climatologically dataset. Results point out enhanced but widespread trends all over the Arctic, temporally and spatially associated with the Arctic changes. Winter wet TCWV trends are clearly observed south of the Svalbard archipelago extending to the Barents Sea. These trends result from persistent local warming phases accompanied by a decline of sea ice. Increasing spring TCWV at the Siberian and the Mackenzie watersheds is thought to result from increased vegetation in areas where snow cover is degrading. Summer sea ice minima events accompanied by clear sky conditions particularly over the Beaufort and west Greenland have favoured a wetter than usual TCWV in both regions. Eurasia and western Alaska experience drier summers; these trends are associated with reported local warmed summers in absence of increased precipitations. However, further investigations are needed to explain these trends. The dramatic decline of fall sea ice extent in the Chukchi and Beaufort regions have led to local enhanced TCWV. This study shows that the TCWV response is more sensitive to the minimum sea ice extent events than the upper ocean temperature changes. Among the most sensitive TCWV regions to this sea ice decline are the Barents (in winter) and the Kara (in fall). The observed anomalies and trends are thought to be reasonably coherent with observations from other data sets.

Acknowledgments: This work was funded by the European project EDU-Arctic. This work was developed in the framework of the VEGA project and supported by the CNRS program LEFE/INSU.

Author Contributions: Dunya Alraddawi, Alain Sarkissian, Philippe Keckhut and Abdanour Irbah conceived and designed the experiments; Dunya Alraddawi performed the experiments; Dunya Alraddawi and Abdanour Irbah analyzed the data; Olivier Bock, Chantal Claud, Slimane Bekki and Mustapha Meftah contributed reagents/materials/analysis tools; Dunya Alraddawi wrote the paper.

Conflicts of Interest: The authors declare no conflict of interest.

\section{References}

1. Polyakov, I.V.; Alekseev, G.V.; Bekryaev, R.V.; Bhatt, U.; Colony, R.L.; Johnson, M.A.; Karklin, V.P.; Makshtas, A.P.; Walsh, D.; Yulin, A.V. Observationally based assessment of polar amplification of global warming. Geophys. Res. Lett. 2002, 29, 25-1-25-4. [CrossRef]

2. Serreze, C.M.; Francis, J.A. The Arctic Amplification Debate. Clim. Chang. 2006, 76, 241-264. [CrossRef] 
3. Ghatak, D.; Miller, J. Implications for Arctic amplification of changes in the strength of the water vapor feedback. J. Geophys. Res. Atmos. 2013, 118, 7569-7578. [CrossRef]

4. Serreze, C.M.; Barrett, A.P.; Stroeve, J.C.; Kindig, D.N.; Holland, M.M. The emergence of surface-based Arctic amplification. Cryosph 2009, 3, 11-19. [CrossRef]

5. Bekryaev, V.R.; Polyakov, I.V.; Alexeev, V.A. Role of polar amplification in long-term surface air temperature variations and modern arctic warming. J. Clim. 2010, 23, 3888-3906. [CrossRef]

6. Cohen, J.; Screen, J.A.; Furtado, J.C.; Barlow, M.; Whittleston, D.; Coumou, D.; Francis, J.; Dethloff, K.; Entekhabi, D.; Overland, J.; et al. Recent Arctic amplification and extreme mid-latitude weather. Nat. Geosci. 2014, 7, 627-637. [CrossRef]

7. Vihma, T. Effects of Arctic Sea Ice Decline on Weather and Climate: A Review. Surv. Geophys. 2014, 35, 1175-1214. [CrossRef]

8. Screen, A.J.; Simmonds, I. The central role of diminishing sea ice in recent Arctic temperature amplification. Nature 2010, 464, 1334-1337. [CrossRef] [PubMed]

9. Chen, Y.; Miller, J.R.; Francis, J.A.; Russell, G.L. Projected regime shift in Arctic cloud and water vapor feedbacks. Environ. Res. Lett. 2011, 6, 44007. [CrossRef]

10. Francis, J.; Hunter, E. Changes in the fabric of the Arctic's greenhouse blanket. Environ. Res. Lett. 2007, 2, 45011. [CrossRef]

11. Miller, R.J.; Chen, Y.; Russell, G.L.; Francis, J.A. Future regime shift in feedbacks during Arctic winter. Geophys. Res. Lett. 2007, 34, 7-10. [CrossRef]

12. Winton, M. Amplified Arctic climate change: What does surface albedo feedback have to do with it. Geophys. Res. Lett. 2006, 33, 1-4. [CrossRef]

13. Screen, A.J.; Simmonds, I.; Deser, C.; Tomas, R. The atmospheric response to three decades of observed arctic sea ice loss. J. Clim. 2013, 26, 1230-1248. [CrossRef]

14. Hansen, J.; Sato, M.; Ruedy, R.; Nazarenko, L.; Lacis, A.; Schmidt, G.A.; Russell, G.; Aleinov, L.; Bauer, M.; Bauer, S. Climate and Dynamics-D18104-Efficacy of climate forcings. J. Geophys. Res. D-Atmos. 2005, 110, 18. [CrossRef]

15. Hansen, J.; Sato, M.; Ruedy, R.; Kharecha, P.; Lacis, A.; Miller, R.; Nazarenko, L.; Lo, K.; Schmidt, G.A.; Russell, G.I.; et al. Dangerous human-made interference with climate: A GISS modelE study. Atmos. Chem. Phys. 2007, 7, 2287-2312. [CrossRef]

16. Graversen, R.G. Do changes in the midlatitude circulation have any impact on the Arctic surface air temperature trend. J. Clim. 2006, 19, 5422-5438. [CrossRef]

17. Sherwood, C.S.; Roca, R.; Weckwerth, T.M.; Andronova, N.G. Tropospheric Water Vapor, Convection and Climate. Rev. Geophys. 2010, 48, 1-29. [CrossRef]

18. Gaffen, J.D.; Robock, A.; Elliott, W.P. Annual cycles of tropospheric water vapor. J. Geophys. Res. 1992, 97, 18185. [CrossRef]

19. Screen, A.J.; Simmonds, I. Half-century air temperature change above Antarctica: Observed trends and spatial reconstructions. J. Geophys. Res. Atmos. 2012, 117, 16. [CrossRef]

20. Ross, J.R.; Elliot, W.P. Radiosonde-based Northern Hemisphere tropospheric water vapor trends. J. Clim. 2001, 14, 1602-1612. [CrossRef]

21. Trenberth, E.K.; Fasullo, J.; Smith, L. Trends and variability in column-integrated atmospheric water vapor. Clim. Dyn. 2005, 24, 741-758. [CrossRef]

22. Mieruch, S.; Noël, S.; Bovensmann, H.; Burrows, J.P. Analysis of global water vapour trends from satellite measurements in the visible spectral range. Atmos. Chem. Phys. 2008, 8, 491-504. [CrossRef]

23. Boisvert, N.L.; Stroeve, J.C. The Arctic is becoming warmer and wetter as revealed by the Atmospheric Infrared Sounder. Geophys. Res. Lett. 2015, 42, 4439-4446. [CrossRef]

24. Boisvert, N.L.; Markus, T.; Vihma, T. Moisture flux changes and trends for the entire Arctic in 2003-2011 derived from EOS Aqua data. J. Geophys. Res. Ocean. 2013, 118, 5829-5843. [CrossRef]

25. Serreze, C.M.; Barrett, A.P.; Stroeve, J. Recent changes in tropospheric water vapor over the Arctic as assessed from radiosondes and atmospheric reanalyses. J. Geophys. Res. Atmos. 2012, 117, 10. [CrossRef]

26. Gao, B.C. Water vapor retrievals using Moderate Resolution Imaging Spectroradiometer (MODIS) near-infrared channels. J. Geophys. Res. 2003, 108, 1-10. [CrossRef] 
27. Alraddawi, D.; Sarkissian, A.; Keckhut, P.; Bock, O.; Noël, S.; Bekki, S.; Irbah, A.; Meftah, M.; Claud, C. Comparison of total water vapour content in the Arctic derived from GPS, AIRS, MODIS and SCIAMACHY. Atmos. Meas. Tech. Discuss. 2017, 5194. [CrossRef]

28. Hall, K.D.; Riggs, G.A. Accuracy assessment of the MODIS snow products. Hydrol. Process. 2007, 21, 1534-1547. [CrossRef]

29. Platnick, S.; King, M.D.; Ackerman, S.A.; Menzel, W.P.; Baum, B.A.; Riédi, J.C.; Frey, R.A. The MODIS cloud products: Algorithms and examples from terra. IEEE Trans. Geosci. Remote Sens. 2003, 41, 459-472. [CrossRef]

30. Huete, A.; Justice, C. Modis Vegetation Index Algorithm Theoretical Basis. Environ. Sci. 1999, $13,129$. [CrossRef]

31. Stow, A.D.; Hope, A.; McGuire, D.; Verbyla, D.; Gamon, J.; Huemmrich, F.; Houston, S.; Racine, C.; Sturm, M.; Tape, K.; et al. Remote sensing of vegetation and land-cover change in Arctic Tundra Ecosystems. Remote Sens. Environ. 2004, 89, 281-308. [CrossRef]

32. Fetterer, F.; Knowles, K.; Meier, W.; Savoie, M. Sea Ice Index, Version 2; National Snow and Ice Data Center: Boulder, CO, USA, 2016. [CrossRef]

33. Mortin, J.; Howell, S.E.L.; Wang, L.; Derksen, C.; Svensson, G.; Graversen, R.G.; Schrøder, T.M. Extending the QuikSCAT record of seasonal melt-freeze transitions over Arctic sea ice using ASCAT. Remote Sens. Environ. 2014, 141, 214-230. [CrossRef]

34. Fichot, G.C.; Kaiser, K.; Hooker, S.B.; Amon, R.M.W.; Babin, M.; Bélanger, S.; Walker, S.A.; Benner, R. Pan-Arctic distributions of continental runoff in the Arctic Ocean. Sci. Rep. 2013, 3, 1053. [CrossRef] [PubMed]

35. Jakobson, E.; Vihma, T. Atmospheric moisture budget in the Arctic based on the ERA-40 reanalysis. Int. J. Climatol. 2010, 30, 2175-2194. [CrossRef]

36. Held, M.I.; Soden, B.J. Robust responses of the hydrologic cycle to global warming. J. Clim. 2006, 19, 5686-5699. [CrossRef]

37. López-Moreno, I.J.; Boike, J.; Sanchez-Lorenzo, A.; Pomeroy, J.W. Impact of climate warming on snow processes in Ny-Ålesund, a polar maritime site at Svalbard. Glob. Planet. Chang. 2016, 146, 10-21. [CrossRef]

38. Onarheim, H.I.; Smedsrud, L.H.; Ingvaldsen, R.B.; Nilsen, F. Loss of sea ice during winter north of Svalbard. Tellus Ser. A Dyn. Meteorol. Oceanogr. 2014, 66, 23933. [CrossRef]

39. Stroeve, C.J.; Markus, T.; Boisvert, L.; Miller, J.; Barrett, A. Changes in Arctic melt season and implifications for sea ice loss. Geophys. Res. Lett. 2014, 41, 1216-1225. [CrossRef]

40. Doxaran, D.; Devred, E.; Babin, M. A 50\% increase in the mass of terrestrial particles delivered by the Mackenzie River into the Beaufort Sea (Canadian Arctic Ocean) over the last 10 years. Biogeosciences 2015, 12, 3551-3565. [CrossRef]

41. Markus, T.; Stroeve, J.C.; Miller, J. Recent changes in Arctic sea ice melt onset, freezeup, and melt season length. J. Geophys. Res. Ocean. 2009, 114, 1-14. [CrossRef]

42. Maslanik, A.J.; Fowler, C.; Stroeve, J.; Drobot, S.; Zwally, J.; Yi, D.; Emery, W. A younger, thinner Arctic ice cover: Increased potential for rapid, extensive sea-ice loss. Geophys. Res. Lett. 2007, 34, 2004-2008. [CrossRef]

43. Woodgate, A.R.; Aagaard, K.; Weingartner, T.J. Interannual changes in the Bering Strait fluxes of volume, heat and freshwater between 1991 and 2004. Geophys. Res. Lett. 2006, 33, 2-6. [CrossRef]

44. Fettweis, X.; Hanna, E.; Lang, C.; Belleflamme, A.; Erpicum, M.; Gallée, H. Brief communication; Important role of the mid-tropospheric atmospheric circulation in the recent surface melt increase over the Greenland ice sheet. Cryosphere 2013, 7, 241-248. [CrossRef]

45. Bennartz, R.; Shupe, M.D.; Turner, D.D.; Walden, V.P.; Steffen, K.; Cox, C.J.; Kulie, M.S.; Miller, N.B.; Pettersen, C. July 2012 Greenland melt extent enhanced by low-level liquid clouds. Nature 2013, 496, 83-86. [CrossRef] [PubMed]

46. Hanna, E.; Fettweis, X.; Mernild, S.H.; Cappelen, J.; Ribergaard, M.H.; Shuman, C.A.; Steffen, K.; Wood, L.; Mote, T.L. Atmospheric and oceanic climate forcing of the exceptional Greenland ice sheet surface melt in summer 2012. Int. J. Climatol. 2014, 34, 1022-1037. [CrossRef]

47. Luo, B.; Luo, D.; Wu, L.; Zhong, L.; Simmonds, I. Atmospheric circulation patterns which promote winter Arctic sea ice decline. Environ. Res. Lett. 2017, 12, 54017. [CrossRef]

48. Lee, S.; Gong, T.; Feldstein, S.B.; Screen, J.; Simmonds, I. Revisiting the cause of the 1989-2009 Arctic surface warming using the surface energy budget: downward infrared radiation dominates the surface fluxes. Geophys. Res. Lett. 2017, 44, 10654-10661. [CrossRef] 
49. Simmonds, I. Comparing and contrasting the behaviour of Arctic and Antarctic sea ice over the 35 year period 1979-2013. Ann. Glaciol. 2015, 56, 18-28. [CrossRef]

50. Vihma, T.; Screen, J.; Tjernström, M.; Newton, B.; Zhang, X.; Popova, V.; Deser, C.; Holland, M.; Prowse, T. The atmospheric role in the Arctic water cycle: A review on processes, past and future changes, and their impacts. J. Geophys. Res. G Biogeosci. 2016, 121, 586-620. [CrossRef]

51. Blunden, J.; Arndt, D.S.; Blunden, J.; Arndt, D.S. State of the Climate in 2015. Bull. Am. Meteorol. Soc. 2016, 97, Si-S275. [CrossRef]

52. Webb, E.E.; Schuur, E.A.G.; Natali, S.M.; Oken, K.L.; Bracho, R.; Krapek, J.P.; Risk, D.; Nickerson, N.R. Increased wintertime CO2 loss as a result of sustained tundra warming. J. Geophys. Res. Biogeosci. 2016, 121, 249-265. [CrossRef]

53. Schaefer, K.; Lantuit, H.; Romanovsky, V.E.; Schuur, E.A.G.; Witt, R. The impact of the permafrost carbon feedback on global climate. Environ. Res. Lett. 2014, 9, 85003. [CrossRef]

54. Biskaborn, K.B.; Lanckman, J.P.; Lantuit, H.; Elger, K.; Streletskiy, D.A.; Cable, W.L.; Romanovsky, V.E. The new database of the Global Terrestrial Network for Permafrost (GTN-P). Earth Syst. Sci. Data 2015, 7, 745-759. [CrossRef]

55. Overland, E.J.; Wang, M.; Salo, S. The recent Arctic warm period. Tellus Ser. A Dyn. Meteorol. Oceanogr. 2008, 60, 589-597. [CrossRef]

56. Perovich, K.D.; Richeter-Menge, J.A.; Jones, K.F.; Light, B. Sunlight, water, and ice: Extreme Arctic sea ice melt during the summer of 2007. Geophys. Res. Lett. 2008, 35, 2-5. [CrossRef]

57. Bunn, G.A.; Goetz, S.J. Trends in satellite-observed circumpolar photosynthetic activity from 1982 to 2003 : The influence of seasonality, cover type, and vegetation density. Earth Interact. 2006, 10, 1-19. [CrossRef]

58. Beck, A.P.S.; Goetz, S.J. Satellite observations of high northern latitude vegetation productivity changes between 1982 and 2008: Ecological variability and regional differences. Environ. Res. Lett. 2012, 7, 29501. [CrossRef]

59. Bhatt, S.U.; Walker, D.A.; Raynolds, M.K.; Comiso, J.C.; Epstein, H.E.; Jia, G.; Gens, R.; Pinzon, J.E.; Tucker, C.J.; Tweedie, C.E.; et al. Circumpolar Arctic tundra vegetation change is linked to sea ice decline. Earth Interact. 2010, 14, 1-20. [CrossRef]

60. Myers-Smith, H.I.; Forbes, B.C.; Wilmking, M.; Hallinger, M.; Lantz, T.; Blok, D.; Tape, K.D.; Macias-Fauria, M.; Sass-Klaassen, U.; Lévesque, E.; et al. Shrub expansion in tundra ecosystems: Dynamics, impacts and research priorities. Environ. Res. Lett. 2011, 6, 45509. [CrossRef]

61. Tape, D.K.; Gustine, D.D.; Ruess, R.W.; Adams, L.G.; Clark, J.A. Correction: Range expansion of moose in Arctic Alaska linked to warming and increased shrub habitat. PLoS ONE 2016, 11, e0160049. [CrossRef] [PubMed]

62. Chapin, S.F. Role of Land-Surface Changes in Arctic Summer Warming. Science 2005, 310, 657-660. [CrossRef] [PubMed]

63. Blok, D.; Heijmans, M.M.P.D.; Schaepman-Strub, G.; Kononov, A.V.; Maximov, T.C.; Berendse, F. Shrub expansion may reduce summer permafrost thaw in Siberian tundra. Glob. Chang. Biol. 2010, 16, 1296-1305. [CrossRef]

64. Blok, D.; Schaepman-Strub, G.; Bartholomeus, H.; Heijmans, M.M.P.D.; Maximov, T.C.; Berendse, F. The response of Arctic vegetation to the summer climate: Relation between shrub cover, NDVI, surface albedo and temperature. Environ. Res. Lett. 2011, 6, 35502. [CrossRef]

65. Loranty, M.M.; Goetz, S.J.; Beck, P.S.A. Tundra vegetation effects on pan-Arctic albedo. Environ. Res. Lett. 2011, 6, 29601. [CrossRef]

66. Myers-Smith, H.I.; Hik, D.S. Shrub canopies influence soil temperatures but not nutrient dynamics: An experimental test of tundra snow-shrub interactions. Ecol. Evol. 2013, 3, 3683-3700. [CrossRef] [PubMed]

67. Piao, S.; Wang, X.; Ciais, P.; Zhu, B.; Wang, T.; Liu, J. Changes in satellite-derived vegetation growth trend in temperate and boreal Eurasia from 1982 to 2006. Glob. Chang. Biol. 2011, 17, 3228-3239. [CrossRef]

68. Buermann, W.; Parida, B.; Jung, M.; MacDonald, G.M.; Tucker, C.J.; Reichstein, M. Recent shift in Eurasian boreal forest greening response may be associated with warmer and drier summers. Geophys. Res. Lett. 2014, 41, 1995-2002. [CrossRef]

69. Kay, E.J.; L'Ecuyer, T.; Gettelman, A.; Stephens, G.; O'Dell, C. The contribution of cloud and radiation anomalies to the 2007 Arctic sea ice extent minimum. Geophys. Res. Lett. 2008, 35, 1-5. [CrossRef] 
70. Parkinson, L.C.; Comiso, J.C. On the 2012 record low Arctic sea ice cover: Combined impact of preconditioning and an August storm. Geophys. Res. Lett. 2013, 40, 1356-1361. [CrossRef]

71. Dufour, A.; Zolina, O.; Gulev, S.K. Atmospheric moisture transport to the arctic: Assessment of reanalyses and analysis of transport components. J. Clim. 2016, 29, 5061-5081. [CrossRef]

72. Comiso, C.J. Large decadal decline of the arctic multiyear ice cover. J. Clim. 2012, 25, 1176-1193. [CrossRef]

73. Maslanik, J.; Stroeve, J.; Fowler, C.; Emery, W. Distribution and trends in Arctic sea ice age through spring 2011. Geophys. Res. Lett. 2011, 38, 2-7. [CrossRef]

74. Stroeve, J.; Serreze, M.; Drobot, S.; Gearheard, S.; Holland, M.; Masalink, J.; Meier, W.; Scambos, T. Arctic sea ice extent plummets in 2007. Geophys. Res. Lett. 2008, 89, 13-20. [CrossRef]

75. Comiso, C.J.; Parkinson, C.L.; Gersten, R.; Stock, L. Accelerated decline in the Arctic sea ice cover. Geophys. Res. Lett. 2008, 35, 1. [CrossRef]

76. Stroeve, C.J.; Kattsov, V.; Barrett, A.; Serreze, M.; Pavlova, T.; Holland, M.; Meier, W.N. Trends in Arctic sea ice extent from CMIP5, CMIP3 and observations. Geophys. Res. Lett. 2012, 39, 1-7. [CrossRef]

77. Mioche, G.; Jourdan, O.; Ceccaldi, M.; Delano, J. Variability of mixed-phase clouds in the Arctic with a focus on the Svalbard region: A study based on spaceborne active remote sensing. Atmos. Chem. Phys. 2015, 15, 2445-2461. [CrossRef]

78. Park, R.D.; Lee, S.; Feldstein, S.B. Attribution of the Recent Winter Sea Ice Decline over the Atlantic Sector of the Arctic Ocean. J. Clim. 2015, 28, 4027-4033. [CrossRef]

79. Maturilli, M.; Herber, A.; König-langlo, G. Surface Radiation Climatology for Ny-Ålesund, Svalbard $\left(78.9^{\circ}\right.$ N), Basic Observations for Trend Detection. Theor. Appl. Climatol. 2015, 120, 331-339. [CrossRef]

(C) 2017 by the authors. Licensee MDPI, Basel, Switzerland. This article is an open access article distributed under the terms and conditions of the Creative Commons Attribution (CC BY) license (http:/ / creativecommons.org/licenses/by/4.0/). 